\title{
Practolol (Eraldin) eye drops as an ocular hypotensive agent
}

\author{
JANET VALE AND G. I. PHILLIPS $\dagger$ \\ Departments of Pharmacology and Ophthalmology, University of Manchester
}

It has been demonstrated that propranolol has the ability to lower the ocular tension in patients with glaucoma when given by intravenous injection (Phillips, Howitt, and Rowlands, 1967; Vale and Phillips, 1970), when applied topically (Bucci, Giraldi, Pecori, Missiroli, and Virno, I968; Vale, Gibbs, and Phillips, 1972), or when given orally (Phillips and others, 1967; Goté and Drance, 1968). However, the topical use of propranolol has a possible disadvantage in that it produces local anaesthesia. (Propranolol also possesses membrane activity which is in part responsible for its action against cardiac arrhythmias. The local anaesthesia and membrane activity are distinct from the $\beta$ receptor blocking properties.) For this reason the effects of other $\beta$-receptor antagonists on ocular tension are being investigated. The one selected for this study was practolol (Eraldin). It is a compound having no local anaesthetic or anti-arrhythmic properties but capable of blocking cardiac $\beta$-adrenergic receptors in doses which have no effect on other $\beta$-receptors (Dunlop and Shanks, 1968). Cardiac $\beta$-receptors are those designated as $\beta_{1}$ by Lands, Arnold, McAuliff, Ludena, and Brown (1967). (Other receptors designated as $\beta_{1}$ by these workers are those involved in lipolysis and in the salivary glands.) The $\boldsymbol{\beta}$-receptors involved in bronchodilatation and vasodilatation are classed as $\boldsymbol{\beta}_{2}$.

The structure of practolol is shown in Fig. I, together with that of propranolol and isoprenaline.

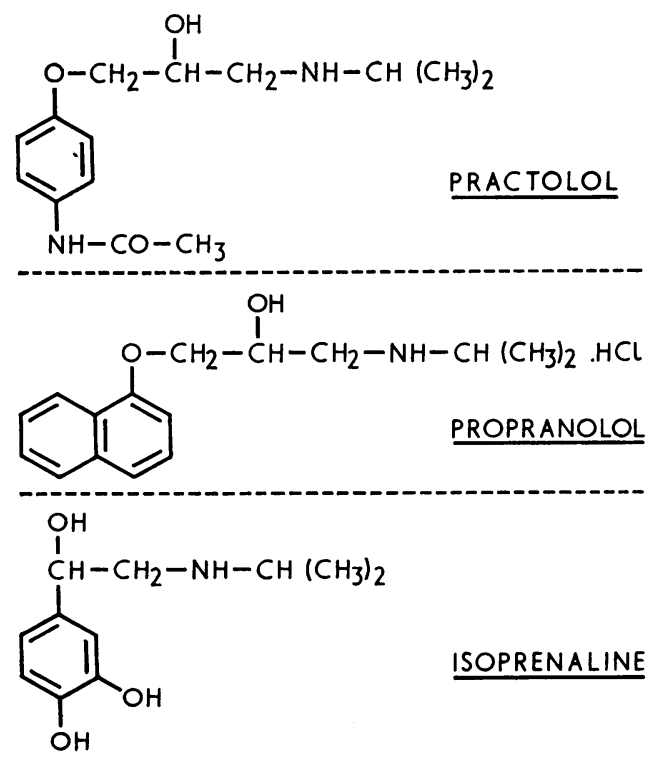

FIG. I Structural formulae of practolol, propranolol, and isoprenaline

Received for publication March ro, 1972

Address for reprints: Janet Vale, Department of Pharmacology, University of Manchester, Oxford Road, Manchester Mr 3 9PL †Present address: Princess Alexandra Eye Pavilion, Chalmers St, Edinburgh EH3 $\mathbf{9 H A}$ 


\section{Method}

Eight patients, three female and five male, aged 38 to 70 years were investigated. The group included five with bilateral open-angle glaucoma, one with borderline bilateral open-angle glaucoma, one with unilateral open-angle glaucoma, and one with definite open-angle glaucoma in one eye and borderline open-angle glaucoma in the other. Six of the patients had previously been treated with pilocarpine eye drops but all treatment was stopped at least 24 hours before admission. The diagnoses and previous treatment of the patients are presented in Table I.

Table I Details of patients in the trial

\begin{tabular}{|c|c|c|c|c|}
\hline Patient & Sex & $\begin{array}{l}\text { Age } \\
\text { (yrs) }\end{array}$ & $\begin{array}{l}\text { Diagnosis of open-angle } \\
\text { glaucoma }\end{array}$ & $\begin{array}{l}\text { Previous medical } \\
\text { treatment }\end{array}$ \\
\hline $\begin{array}{l}\text { A } \\
\text { B } \\
\text { G } \\
D \\
\text { E } \\
\text { F } \\
\text { G } \\
\text { H }\end{array}$ & $\begin{array}{l}\mathbf{M} \\
\mathbf{F} \\
\mathbf{F} \\
\mathbf{M} \\
\mathbf{M} \\
\mathbf{F} \\
\mathbf{M} \\
\mathbf{M}\end{array}$ & $\begin{array}{l}49 \\
62 \\
70 \\
60 \\
67 \\
38 \\
54 \\
67\end{array}$ & $\begin{array}{l}\text { Left; right borderline } \\
\text { Bilateral } \\
\text { Bilateral } \\
\text { Left } \\
\text { Bilateral } \\
\text { Bilateral } \\
\text { Borderline bilateral } \\
\text { Bilateral }\end{array}$ & $\begin{array}{l}\text { Pilocarpine } 2 \text { per cent. } \\
\text { Pilocarpine } 2 \text { per cent. } \\
\text { Pilocarpine } 4 \text { per cent. } \\
\text { Pilocarpine } 2 \text { per cent. } \\
\text { None } \\
\text { Pilocarpine } 2 \text { per cent. } \\
\text { None } \\
\text { Pilocarpine } 2 \text { per cent. }\end{array}$ \\
\hline
\end{tabular}

The trial was arranged in a double-blind cross-over pattern, each patient acting as his own control. On the first day one eye (right or left), chosen at random, received drops of practolol ro per cent, the other eye receiving drops of vehicle. For both eyes readings of ocular tension by applanation tonometry were made at 9.30, I0.00, 10.30, and I I a.m., I 2.00 noon, I.30, 2.00, 2.30, 3.00, 4.00, and 5.30 p.m. One drop of practolol or vehicle was instilled into the chosen eye immediately following the 9.30, 1.30, and 5.30 readings. 'The same allocation of drops was made on the second day (i.e. the eye that received practolol on the first day also received it on the second day). On the third day the allocation of practolol and vehicle was reversed; this regimen was repeated exactly on the fourth day. (Thus the eye receiving practolol initially received vehicle later and vice versa.) Each eye received practolol for 2 days and vehicle for 2 days, with a changeover after 2 days, except for patients $\mathrm{G}$ and $\mathrm{H}$ in whom the trial lasted 6 days with the change of drops after 3 days.

The drops, practolol ro per cent., and vehicle, were supplied by Imperial Chemical Industries (Pharmaceuticals Division). A concentration of ro per cent. was chosen because a short preliminary investigation showed that this had no irritant effect when instilled into the conjunctival sac in man.

\section{Analysis of results}

As was discussed fully in a previous paper (Vale and others, 1972), a reading of ocular tenston in any one patient will be influenced by several factors, including the eye used, the day of the investigation, the time of day, and the treatment (practolol or vehicle) received by the eye. This investigation was designed to determine whether there existed a statistically significant difference in the tension as a result of the treatment received. Such a determination, however, must take into account and allow for the above factors and, in order to do this, an analysis of variance was done. The analysis gave estimates of the changes attributable to the difference in the effect of practolol and vehicle and the time at which practolol produced its maximum effect.

\section{Results}

By means of this analysis of variance, the $F$ value, maximum fall, and time of maximum fall for each patient was obtained. These are shown in Table II (overleaf), with the significance of the effect of practolol. From this Table, practolol produced a significant $(\mathrm{P}<0 \cdot 025)$ lowering of the ocular tension in six $(\mathrm{B}, \mathrm{C}, \mathrm{D}, \mathrm{F}, \mathrm{G}$, and $\mathrm{H})$ out of the eight 
Table II F values, maximum falls and significance of results for the eight patients

\begin{tabular}{|c|c|c|c|c|}
\hline Patient & $\begin{array}{l}\text { Maximum fall } \\
(\mathrm{mm} . \mathrm{Hg})\end{array}$ & $\begin{array}{l}\text { Time of } \\
\text { maximum fall }\end{array}$ & $F$ value* & Significance \\
\hline A & $I \cdot 75$ & 2.30 p.m. & $\mathrm{I} \cdot 73$ & $\mathrm{P}>0.05$ (n.s) \\
\hline B & 5.00 & I.3o p.m. & $3 \cdot 70$ & $\mathrm{P}<0.025$ \\
\hline C & $5 \cdot 75$ & $\mathrm{I} 2.00$ a.m. & $2 \cdot 25$ & $\mathrm{P}<0.025$ \\
\hline D & 5.00 & $2 \cdot 00$ p.m. & $4 \cdot 92$ & $\mathrm{P}<0.025$ \\
\hline $\mathrm{E}$ & $2 \cdot 00$ & 3.00 p.m. & 0.75 & $\mathrm{P}>0.05$ (n.s) \\
\hline $\mathrm{F}$ & $5 \cdot 25$ & 12.00 a.m. & $4 \cdot 12$ & $\mathrm{P}<0.025$ \\
\hline G & $\mathrm{I} \cdot 85$ & I I 30 a.m. & $2 \cdot 62$ & $\mathrm{P}<0.025$ \\
\hline $\mathrm{H}$ & $6 \cdot 15$ & $3 \cdot 30$ p.m. & $15 \cdot 90$ & $\mathrm{P}<0.025$ \\
\hline
\end{tabular}

*The $\mathrm{F}$ value should be tested with $\mathrm{io}$ and 63 degrees of freedom for patients $A, B, C, D, E, F$, with 10 and 105 for patient $G$, and with Io and I Io for patient $\mathrm{H}$.

patients in the study. Four patients $(\mathrm{B}, \mathrm{C}, \mathrm{F}$, and $\mathrm{G})$ showed the maximum fall between 2 and 3 hours after the first instillation of drops. In the other four patients $(\mathrm{A}, \mathrm{D}, \mathrm{E}$, and $\mathrm{H}$ ), the maximum fall occurred between $30 \mathrm{~min}$. and 2 hours after the second instillation.

Fig. 2 shows the mean lowering in tension in $(a)$ all eight patients and $(b)$ in the six in whom the result was significant. Fig. 3 compares the effect of practolol with that of propranolol, only the significant results being used in each case. At no time is there a significant difference in the effect produced by practolol io per cent. and that produced by propranolol i per cent. In Fig. 3 the fall in ocular tension after the first instillation of practolol is greater (but not significantly) than that following the first instillation of propranolol; with the former there is a rise starting $2 \frac{1}{2}$ hours after instillation which is not shared by the latter. After the second instillation of practolol the tension shows a very similar pattern of fall and rise to that following the second instillation of propranolol. The maximum lowering of tension in the significant results was very similar for practolol and propranolol: see Fig. 3 .

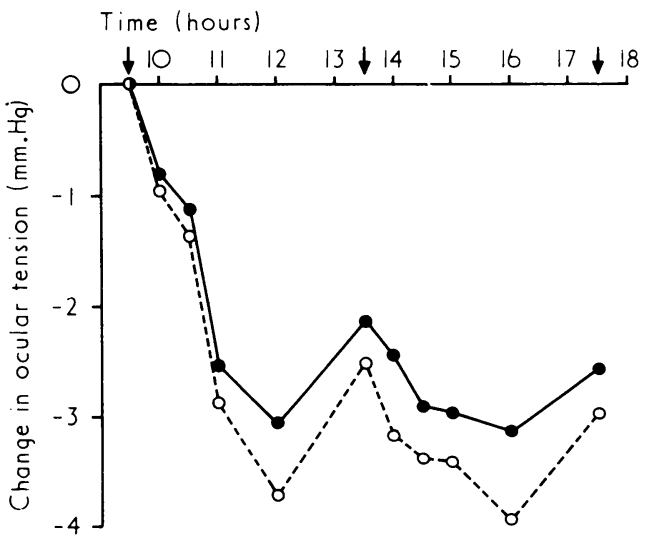

FIG. 2 Change in ocular tension after topical practolol io per cent. Closed circles-mean of all eight patients. Open circles-mean of six patients in whom the effect was significant

Arrows indicate times at which drops were instilled

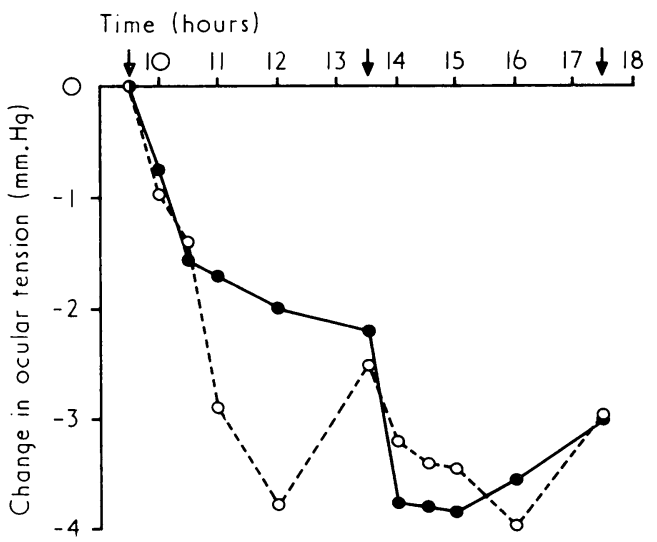

FIG. 3 Comparison of change in ocular tension after topical practolol io per cent. and topical propranolol I per cent. Open circles-practolol, mean of significant results. Closed circles-propranolol, mean of significant results

Arrows indicate times at which drops were instilled 


\section{Discussion}

The results show that topically administered practolol at a concentration of 10 per cent. causes a significant lowering of the ocular tension in glaucoma patients. The poorest response in an individual was a maximum fall in tension of $\mathrm{I} \cdot 75 \mathrm{~mm}$. $\mathrm{Hg}$ and the greatest response was a maximum fall of $6.15 \mathrm{~mm}$. $\mathrm{Hg}$; the mean in all patients was a fall of 4.09 $\mathrm{mm} . \mathrm{Hg} \pm 0.66$ (s.e.m.). With topical propranolol I per cent. the results were $\mathrm{I} \cdot 5$, $6 \cdot 5$, and $4 \cdot 35 \mathrm{~mm}$. $\mathrm{Hg}$ respectively (Vale and others, 1972 ).

Practolol is selective in blocking cardiac $\beta$-adrenergic receptors $\left(\beta_{1}\right)$. At these receptors practolol has only $\frac{1}{3}$ or $\frac{1}{4}$ the effectiveness of propranolol in blocking isoprenaline (Dunlop and Shanks, I968). This, taken with the higher concentration of practolol used (Io per cent. compared with I per cent.) would suggest that practolol should have a greater effect on ocular tension than propranolol, if the two are acting by the same mechanism, i.e. a block of those $\beta$-adrenergic receptors classed as $\beta_{1}$ by Lands and others (1967). However, a greater effectiveness was not observed, the two compounds having a similar overall effect.

A consideration of the literature reveals that the relationship between changes in ocular tension and compounds affecting adrenergic receptors is complex. Isoprenaline, which stimulates all $\beta$-adrenergic receptors, causes a fall in tension (Weekers, Delmarcelle, and Gustin, I955; Ross and Drance, I 969) as does salbutamol (Paterson and Paterson, I 97 I), a compound which appears to be a selective stimulator for $\beta$-adrenergic receptors of the type found in bronchial smooth muscle (Brittain, Farmer, Jack, Martin, and Simpson, I968), i.e. $\beta_{2}$. These two observations might suggest that there are present in the eye receptors of this type $\left(\beta_{2}\right)$ which cause a fall in ocular tension when stimulated. However, noradrenaline, which stimulates $\alpha$-receptors and cardiac $\beta$-receptors, also produces a fall in ocular tension in rabbits, but it seems likely that this is due to stimulation of $\alpha$-receptors (Eakins and Ryan, I 964). It appears that both $\alpha$ - and $\beta$-adrenergic stimuli are able to produce a similar effect on outflow of aqueous humour, at least in the rabbit (Gnädinger and Bárány, i 964). Such a situation may also exist in the human eye. It is now well documented that propranolol produces a fall in ocular tension in man and it seems that the major portion of this effect must be due to $\beta$-blockade, as the d-isomer, which has virtually no $\beta$-blocking activity has little tension-lowering effect (Vale and Phillips, 1970). That the local anaesthetic activity of propranolol is totally responsible for the lowering in tension, as suggested by Musini, Fabbri, Bergamaschi, Mandelli, and Shanks (1971), seems highly unlikely in view of this difference between racemic and dextro-propranolol (the dextro and laevo forms have approximately equal activity as local anaesthetics: Barrett and Cullum, i968). Propranolol has not been shown to exhibit any selectivity at $\beta$-adrenergic receptors, so we can assume that it will block all those present in the eye including those by which salbutamol produces its tension-lowering effect. It has been suggested by Bill (1970) that in the monkey eye there are $\beta$-receptors in the chamber angle tending to increase facility of outflow and reduce pressure, and $\beta$-receptors in the ciliary muscle tending to decrease facility and increase pressure as well as $\beta$-receptors which stimulate aqueous secretion and increase pressure. An experiment in vitro with rabbit ciliary epithelium has shown that :soprenaline stimulates active transport of $\mathrm{Na}^{+}$across the ciliary epithelium (Cole and Nagasubramanian, 1972). A compound which blocks all $\beta$-receptors will thus have the possibility of affecting the pressure in these three ways. If these receptors all exist in the human eye, it could be that they are different types of $\beta$ receptor, and it would not be impossible that a $\beta_{2}$ agonist and a $\beta_{1}$ antagonist should both produce a fall in tension. This would explain the apparent anomaly that both salbutamol and practolol produce a fall in ocular tension. 
One reason for the rather unexpectedly weak activity of practolol compared with propranolol may be that practolol possesses some intrinsic sympathomimetic activity which, with more than one possible site of action available, gives a complex situation. The absence of any local anaesthetic activity may also be a factor.

In an attempt to determine whether or not patients become resistant to the tensionlowering effects of practolol, a short trial was carried out involving five patients (not those studied previously) who showed a response to practolol when in hospital. The patients (four male, one female) received outpatient treatment with practolol io per cent. to one eye only for periods ranging from $2 \frac{1}{2}$ to $3 \frac{1}{2}$ months. The patients returned to hospital for a few days, the practolol drops were replaced by vehicle drops, and the ocular tensions were determined at regular intervals for a period of 3 days. In none of the patients was there definite evidence of a rise in tension in the eye from which practolol had been withdrawn. There are two possible explanations for this: either the practolol had a longlasting effect and the period of observation was too short or the practolol had ceased to produce any effect when used repeatedly over several weeks. This point requires further investigation.

\section{Summary and conclusion}

A trial with eye drops of 10 per cent. practolol, a cardioselective $\beta$-adrenergic receptorblocking drug, in a group of patients with open-angle glaucoma demonstrated the ability of the drug to reduce ocular tension. The reduction was statistically significant although not marked. The io per cent. concentration of practolol used gave a reduction of similar magnitude to that previously obtained by the use of I per cent. propranolol eye drops.

It is suggested that the lowering of the tension is mediated by a blocking effect on $\beta$-adrenergic receptors.

We are grateful to Dr. R. A. Wiseman and I.C.I. (Pharmaceuticals) Ltd. for generous supplies of practolol and vehicle eye drops and helpful discussions; and to A. C. C. Gibbs, Department of Social and Preventive Medicine, University of Manchester, for the statistical analysis.

\section{References}

Barrett, A. M. and cullum, v. A. (1968) Brit. J. Pharmacol., 34, 43

BILl, A. (1970) Exp. Eye Res., I0, 3 I

BritTAin, R. T., FARMER, J. B., JAGK, D., MARTin, L. E., and simpson, w. T. (ig68) Nature (Lond.),

219, 862

BUCGi, M. G., Giraldi, J., PECORI, A., Missiroli, A., and virno, m. (I968) Boll. Oculist., 47, $5^{1}$

Cole, D. F., and Nagasubramanian, s. (1972) Exp. Eye Res., 13, 45

COTÉ, G., and DRANCE, s. M. (1968) Canad. J. Ophthal., 3, 207

DUNlop, D , and shanks, R. G., (1968) Brit. J. Pharmacol., 32, 20 I

EAKINS, K. E., and RYAN, s. J. (1964) Ibid., 23, 374

GNÄDINGER, M. C., and BÁRÁNy, E. H. (1964) v. Graefes Arch. Ophthal., 167, 483

LANDS, A. M., ARnold, A., Mcauliff, J. J., Luduena, F. P., and Brown, T. G. (1967) Nature (Lond.),

2r4, 597

mUSini, A., fAbBri, B., Bergamaschi, m., mandelli, v., and shanks, R. g. (I97i) Amer. J. Ophthal., 72,

773

PAterson, G. D., and Paterson, G. (I97 I) Postgrad. med. J., 47, suppl. I 22

Phillips, c. I., hOWITT, G., and Rowlands, D. J. (ig67) Brit. J. Ophthal., 51, 222

Ross R. A., and Drance, s. M. (i969) Canad. J. Ophthal., 4, 352

vale, J., GibBs, A. c. C., and Phillips, c. I. (I972) Brit. $\mathcal{J}$. Ophthal., 56, 770

and Phillips, c. I., (1970) Exp. Eye Res., 9, 82

Weekers, R., Delmargelle, y., and gustin, J. (1955) Amer. J. Ophthal., 40, 666 